p-ISSN 1693-1246

e-ISSN 2355-3812

June 2020
Jurnal Pendidikan Fisika Indonesia 16 (1) (2020) 14-23

DOI: 10.15294/jpfi.v16i1.14253

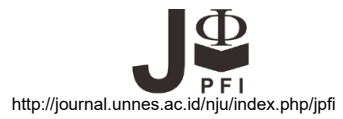

\title{
Influence of Problem Based Learning Model on Student Mental Models
}

\author{
J. R. Batlolona ${ }^{1 *}$, S. Singerin², M. Diantoro ${ }^{3}$ \\ ${ }^{1}$ Teacher Professional Education Study Program, Faculty of Teacher Training and Education, \\ Universitas Pattimura, Indonesia \\ ${ }^{2}$ Physics Education Study Program, Faculty of Teacher Training and Education, \\ Universitas Pattimura, Indonesia \\ ${ }^{3}$ Physics Study Program, Faculty of Mathematics and Natural Sciences, \\ Universitas Negeri Malang, Indonesia
}

Received: 3 January 2020. Accepted: 18 March 2020. Published: 30 June 2020

\begin{abstract}
The purpose of this study was to determine the development of mental models (MM) of students as well as to analyze the differences in MM based on the learning model used. This research is expected to be a guide for teachers in exploring the concept of physics as a whole. The study was conducted at the high school level with a medium level school category. The research method used mixed methods embedded experimental models with surface level, matching and deep (SMD) diagnostic test instruments. The results of the study showed that there were an increase on students' MM at each meeting in the SMD level. Other results show that there are differences in the mean scores corrected between levels of the learning model. The mean score corrected PBL mental model is significantly different from conventional. The increase in MM students with PBL was higher than the increase in MM students with conventional learning. Thus, PBL can be recommended to increase MM students' physics of high school students.
\end{abstract}

Keywords: Elasticity; Mental Models; PBL

\section{INTRODUCTION}

The mental model in principle is an internal representation of several domains that support understanding of a problem. Mental models represent more complex forms of conceptual knowledge that have a causal relationship. The main characteristic of the mental model is the structure associated with knowledge about the real world and the phase of processing knowledge which is a unit of memory by involving symbols that reflect the knowledge of knowledge itself, thus giving birth to better learning processes (Ahi, 2016).

Mental models are built from individual cognitive representation systems, representing simplifications, illustrations, analogies, and simulations of real objects. In order to understand new knowledge or certain phenomena, mental models that are built refer to previous knowledge, with the information presented

${ }^{*}$ Correspondence Address:

JI. Dr. J. A Tamaela, 97117, Ambon Indonesa

E-mail: johanbatlolona@gmail.com allowing it to be interpreted (Reinfried \& Tempelmann, 2014). Therefore, in building mental model for a beginner is different from someone who is an expert in his field. So, in modifying learning very depends on the mental model of an individual who already has a certain amount of knowledge which called conceptual change (Banks \& Millward, 2000).

Students can use mental models to understand invisible physics phenomena, such as those that occur on a microscopic scale. Educational psychologists explain that mental models are internal thoughts that act as a structural analogy of a situation or process (Stains \& Sevian, 2015). Its role when someone tries to understand, explain, and have a good prediction of a phenomenon (Greca \& Moreira, 2000). Understanding mental models allows the development of more effective communication and decision making (Lin \& Chiu, 2007).

The mental model process can be used to investigate physical concepts and the information can be accessed by the teacher so that it helps in building students' understanding 
of concepts (Itza-Ortiz, Rebello, \& Zollman, 2004). One of the topics of physics taught in learning is elasticity. The teacher's task is not only to teach the concept macroscopically but also microscopically and it must be considered. The teacher will give structured questions from the lowest level to the highest level. Information about the development of student mental models for each meeting has not been well explored, so teachers are not able to map the mental models of students as evaluation materials for learning in each learning (Dankenbring \& Capobianco, 2016). Mental models in physics learning indicate the right reasons in compiling good knowledge in explaining explicitly the assumptions about a phenomenon (Hubber, 2006).

There is still a constrain in implementing contextual teaching in high school physics in Malang. The learning is still a teacher centered mode, so that students are less given opportunity to develop their conceptual knowledge at the microscopic level. As a result students become confused in developing a conceptual framework. This is in accordance with Adbo \& Taber (2009) finding that such learning processes have an impact on student boredom and also affect students' cognitive learning outcomes in physics.

The results of physics learning at a number of high schools in Malang reported by Yogantari (2015) revealed that as many as $35 \%$ of students experienced difficulties in the material Elasticity and Hooke Law, $30 \%$ in Optics, and $15 \%$ in Kinematics. The difficulty is caused by less optimal learning process especially in hands on activity experienced by students. As many as $76 \%$ of students stated that learning in the classroom was still dominated by the teacher as a learning resource. As many as $14.6 \%$ of students found it difficult to understand the physics presented in the form of diagrams, $33 \%$ had difficulty understanding concepts, $38 \%$ had difficulty using mathematical representations, and the rest had difficulty making conclusions based on analysis. Research results also prove that high school students in Malang still find it difficult in the topic of Hooke Law and Series and Parallel Series (Batlolona, Diantoro, Wartono, \& Latifah, 2019). Difficulty in understanding physical concepts shows that misconceptions occur and concept mastery is still low. Both of these factors indicate that students' mental models are still low.

Future physics learning in high schools in global is directed to prepare students to be able to obtain good knowledge so that what they obtain can be used to solve problems in everyday life. But many researchs proves that high school students still have difficulty in understanding physics concepts well, for example on the topic of temperature and heat (Schnittka \& Bell, 2011); energy (Gabe-Thomas, Walker, Verplanken, \& Shaddick, 2016); electric chain (Doran, Böhm, \& Hanss, 2018); static electricity (Bongers, Northoff, \& Flynn, 2019); light (Furlough \& Gillan, 2018); the concept of motion in Newton's law (Langbeheim, 2015); thermal equilibrium (Fernandez, 2017). This is because that many people think the teacher can transmit knowledge from one person's mind to another person's mind, so that the teacher plays a more active role in learning. Thus students can only hear, record, and work on the instructions given by the teacher, finally learning is only centered on the teacher (Smit, de Brabander, \& Martens, 2014).

Difficulties in learning physics result in low student learning outcomes. This is due to the lack of exploration and empowerment of students' mental models of physics. Physics learning is currently more directing students to the completion of the material rather than mastery of physics concepts. Even though the teacher do not quitely concern that by mastering a good physics concept, it has an effect on improving student learning outcomes

Topic of elasticity is an important part of learning physics and everyday life. This can be seen when almost all human activities to protect the limbs whether head, body and feet use elastic material. Mental models are very suitable when collaborating with material elasticity. Mental models explain the macroscopic and microscopic state of a material so students will get used to explaining how the state of a particle or molecule is given force.

Problem based learning (PBL) is one of the pedagogical approaches that allows students to learn actively with meaningful problems. Where students are given the opportunity for authentic problem solving through collaborative learning in encouraging mental enhancement of student models in learning (Hmelo-Silver, 2004). The study results report that with PBL students gain learning experiences through developing questioning and thinking skills to solve physics problems (Hapsoro \& Susanto, 2011). Each phase of PBL stages has the potential to facilitate students in improving their quality of mental models that stimulates better changes in the structure of thinking 
(Servant-Miklos, 2019). Group learning activities in order to solve problems or cases, encourage students to think with their knowledge, identify information needed, find more relevant information, and analyze and evaluate in order to arrange the problem solving. These activities have an impact on changing the mental models of students. In addition, the involvement of real experiences in learning is expected to stimulate students 'mental models and increase students' creative thinking skills in physics $(O$ Doherty, Mc Keague, Harney, Browne, \& McGrath, 2018). PBL has the potential to change students' mental models. Students 'real experiences in learning can be further enhanced by creating learning situations through students' mental models (Lycke, Grøttum, \& Strømsø, 2006).

Studies of mental physics models and PBL are still limited and were be done separately. That is research on mental models of physics concepts only or learning physics with $\mathrm{PBL}$ only (Chiou \& Anderson, 2010). Mental models using PBL learning models on the material elasticity of solid material have never been studied. Therefore it needs a comprehensive and in-depth study of the process of change or the development of mental models of students by applying the PBL model in physics learning. Therefore, the purpose of this study is to find out how PBL influences students' mental models on the material elasticity of solids.

\section{METHOD}

This study was used a mixed methods to explore the research subject. Research conducted using the embedded experimental model design (Cresswell \& Clark, 2007) as illustrated in Figure 1.

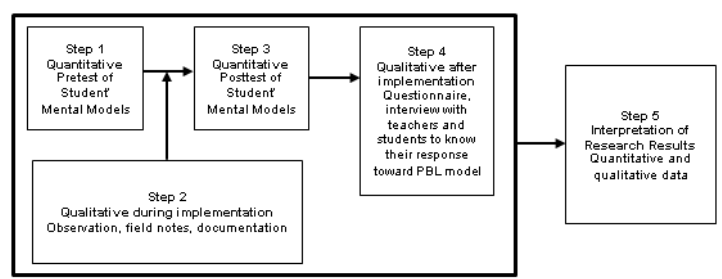

Figure 1. Embedded Research Design (Adaptation from Creswell \& Plano, 2007: 68)

The first step is to conduct a pretest to find out the mental model of students with the form of problem description before the PBL model is implemented. Problem description consists of 10 diagnostic questions in one con- cept. Pretest results are used as quantitative data. Then the intervention was carried out in the form of implementing PBL model learning.

The second step, intervening with PBL implementation, qualitative data collection were carried out in the form of observing the implementation of the PBL Learning Implementation Plan (RPP) as well as the development of students' mental models. The observation activity was assisted by five observers and the learning activities were documented with photos and videos. Obervation activities include various aspects of the material being studied including elastic and non-elastic objects, stress, strain and Young's modulus, Hooke's Law in paralel and series arrangements of springs.

The third step was posttest about the students' mental models with the same questions as in the pretest session. The fourth step was conducted to collect qualitative data about teachers and students responses through questionnaire responses and interviews toward PBL implementation. The questionnaire consist of 10 questions which were related to teachers and students' satisfaction regarding with learning using the PBL model and followed by interview. After all the stages have been carried out, interpretations of the results of the qualitative data collections has been carried out and triangulate them with quantitative data in order to draw conclusions in accordance with the formulation of the research problem.

This research was conducted at SMA Negeri 8 Kota Malang. The school is included in the medium level, which means the sample of students in heterogeneous classes because the academic ability of students in one class is not homogeneous or varied (high, medium, and low). The research subjects in this study are class $X$ students who are determined by random sampling through lottery techniques so that two classes are obtained which are the experimental and control classes. The samples in this study were 77 students, those who were determined randomly.

Data collections were conducted by observation, in-depth interviews, and tests. Observations were made by using mental model observation sheet related to student activities and carried out in every meeting and were observed by three observers who have been trained. The observations were carried out four times with different sub topics including elastic and non-elastic objects; stress, strain, and Modulus Young; Hooke's law; and series and parallel of springs arrangements. In-depth in- 
terviews were conducted to reconfirm student answers after working on student worksheets (LKS) on each sub topic or meeting. Interview questions were addresed to ten best questions developed from the four sub topics. The last data were collection techniques through mental model tests before treatment (pretest) and after treatment (posttest) with PBL.

In the control class using the usual learning patterns without any special treatment for students. Students who experience learning with this pattern, usually do not get special attention from the teacher in improving students' mental models. The learning approach applied is conventional in nature, which is centered on the teacher as a source of learning, so that students' skills in reconstructing their abilities are not facilitating.

The instrument in this study uses a diagnostic test developed by Ifenthaler (2006) in the form of a structured essay of 10 questions. The instrument used had passed the instrument testing stage at SMA 2, SMA 4, SMA 5, and Santa Maria High School Malang. The test results revealed the value of the instrument content validity of 0.72 and reliability of 0.86 which was analyzed by the SPSS 23.00 for Windows program. The mental model includes three indicators, namely surface (S), Matching (M), and Deep (D). The type of mental model questions are diagnostic tests consisting of three levels on one question. The assessment is determined by reference, namely 1) If the student answers point 1 correctly then the student has a Surface mental model (S), 2) If the student answers point 1 and 2 correctly then the student has a Matching mental model (M) and 3) If students correctly answer points 1,2 and 3 then the student has a Deep mental model (D) as shown in Table 1.

Table 1. Indicators of the Mental Model SMD Assessment According to Ifenthaler (2006)

\begin{tabular}{cl}
\hline Type & Assessment criteria \\
\hline S & $\begin{array}{l}\text { Students answer correctly but are } \\
\text { unable to give reasons or reasons } \\
\text { given scientifically incorrect }\end{array}$ \\
M $\quad \begin{array}{l}\text { Students answer correctly by giving } \\
\text { explanations or reasons correctly }\end{array}$ \\
D $\quad \begin{array}{l}\text { students answer correctly and give } \\
\text { correct explanations, in addition to } \\
\text { being able to give scientifically cor- } \\
\text { rect answers to predictive questions. }\end{array}$
\end{tabular}

Data analysis used in this study uses descriptive and inferential statistics. Descriptive data analysis was performed to determine the development of students' mental models at each level in each learning. Besides testing the PBL mental models with conventional learning. Data analysis through inferential statistics with anacova test was carried out to test the hypothesis using pretest and posttest data assisted by SPSS 23.00 for windows program. In the analysis, the pretest data functions as a covariate. If the anacova test results show that the $F_{\text {count }}$ value is significantly different, then proceed with the LSD (Least Significance Difference) test.

Normality and homogeneity data tests are performed first as a condition for hypothesis testing. Normality test is used to ensure that the pretest and posttest data are normal, while the homogeneity test is to ensure the data is homogeneous. The independent variable in this study is a learning model consisting of $P B L$ and conventional learning models. Control variables include the teacher who taught, the number of hours of learning, teaching materials, LKPD (Student Worksheet) used by students, and the test instruments. The type of data obtained from the results of the SMD assessment of students' mental models is the ratio.

\section{RESULTS AND DISCUSSION}

The first steps in PBL is orientation to problems related to the concept of elasticity and directed in making hypotheses about physics phenomena given by the teacher. From these activities students are directed to be able to solve the initial problems given by the teacher through experience and abilities previously obtained so that the initial mental model will play an active role in solving problems at a simple level (Pasco \& Ennis, 2015). The next step, the teacher organized students in heterogeneous groups by giving a case about the plane. The question raised from this case is why the wheels of the plane are made with a small size to carry on the large scale of the plane. The next question in this case is what is the state of tire particles when the plane is landing. In this case, students will provide a scientific view in accordance with the concepts they have learned.

Reconstruction of the mental model of students has begun to experience a good increase where the average student gives alternative answers to the case. The third stage is to guide individual or group investigations. In 
this stage students are directed to find themselves and solve themselves based on a given theory. The case arises is using a spring, but replaced with a sponge. In this section measure the constant of a sponge when given a mass increase. Thus the mental models of students that are formed are stronger because they find something new in reconstructing previous theories. Therefore students will confirm the findings with the theory developed (Cheng \& Lin, 2015). Stage four is that students are directed to develop and present their work in front of the class based on the findings. So there is a good exchange of information between one group and another. The fifth stage is analyzing and evaluating the problem solving process (Stewart \& Bower, 2019). All the stages that are present provide a great opportunity in improving students' mental models

During the learning process, students were given a mental model score on each indicator based on the assessment rubric. The categories obtained by students if the score 1 is good enough, 2 is good, and 3 is very good. In this study students are considered to have a mental model if they are at a high level and very good. The results of observations of mental models of students at each meeting from one to four experienced a significant increase from the level of not answering to deep. These results are presented in Figure 2 untill Figure 5.

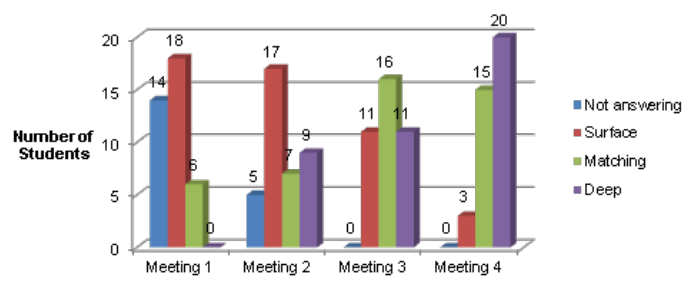

Figure 2. Mental models of students at meetings 1 to 4

At the first meeting students amounted to $36.84 \%$, still in the category of not good, quite good/surface $(47.37 \%)$, good/matching $(15.79 \%)$ and at this first meeting there were no students in the deep category. This is because students are still not familiar with the learning patterns applied.

At the second meeting five students occupied the unfavorable category $(13.16 \%)$, the moderately good category/surface (44.74\%, the good/matching category $(18.42 \%)$ and the deep category $(23.68 \%)$. students are getting used to the learning patterns that are applied and students' conceptual structures begin to be formed.

At the third meeting no longer found students who were in the poor category, the surface $28.94 \%$, the good/matching category $(42.12 \%)$ and the deep category $(28.94 \%)$. This is because students are familiar with the learning patterns that are applied and the conceptual structure of students has been formed.

At the fourth meeting there were no more students who were in the unfavorable, fairly good/surface $(7.89 \%)$, good/matching $(39.48 \%)$ and deep $(52.63 \%)$ categories. This is because students have found good learning patterns by applying PBL learning models so that the structure of students' knowledge has been good and students have not experienced misconceptions but have a conceptual fit with the views of physicists.

The information shows that PBL shows its existence in increasing MM students in each meeting. In each phase, facilitate in increasing MM students. In addition PBL trains more skills to improve the mastery of concepts, connect theoretical and practical abilities, motivate students to learn, think critically and creatively (William, Harvey, \& Lawson, 2007; Wartono, Diantoro, \& Batlolona, 2018) At the last meeting more many students are at the level of matching and deep. This shows that the conceptual physics of students has been good. Another influential factor is that students are disciplined in learning according to the teacher's instructions so that all learning phases at each meeting can run well. Similarly, learning outcomes in the experimental class when compared with conventional classes. Conventional classes, focus more on the teacher than students in developing thinking skills (Aldarmahi, 2016). PBL class students discuss more with peers in exchanging information on physical knowledge (Hodges, 2018). Anacova test results on the effect of learning models on mental models are shown in Table 2.

The results of the hypothesis test in Table 2 show that the significance value of the $F$ calculated learning model is 0.000 . This value is smaller than alpha $(0.05)$. This means that the null hypothesis $\left(\mathrm{H}_{0}\right)$ which states there is no effect of the learning model on students' mental models is rejected, so the learning model has a significant effect on students' mental models. The LSD (Least Significant Difference) (Leasa \& Corebima, 2017) test results are shown in Table 3.

The results of the study prove that the learning model has a significant effect on the 
mental models of students, in this case PBL shows a greater effect compared to conventional learning. How PBL can have a significant influence needs to be studied in depth. Besides that the mean score of the PBL mental model corrected was significantly different from conventional. The increase in MM of students with $\mathrm{PBL}$ is higher than the increase in MM of students in conventional learning.

In a learning process that is found is a variety of thinking between students. This is evidenced by the different student concepts. Therefore from the differences that are needed a good concept by combining different thoughts to give birth to an idea or concept that is true. This pattern is formed from a series of individual activities that form a group to discuss problems that must be solved together. By combining ideas from groups will build mental models of student physics models.

PBL applies and provides modeling to solve a problem with a similar structure. Therefore students are required to solve these problems. Problems that are structurally different, it will require students to identify the problem also structurally. With a different structural will help them to develop mental model schemes that are stronger than various types of problems (Scott, 2014). In learning, students' conceptual knowledge is different, concepts are formed individually, therefore students need to be seated in groups to equalize perceptions, strengthen existing mental models.

The concepts formed in groups are representations of memory to stimulate students' cognition to be more sensitive. When a mem- ber explains a concept, the group's mental model will change so that it triggers new ideas and enriches it to create new knowledge (Rentsch, Mello \& Delise, 2010). Learning with PBL students are stimulated to be more active, which is characterized by problems as the main trigger then students actively to build mental models and find alternative solutions (Williams \& Paltridge, 2017).

Problem solving in PBL is practical, meaning that students directly carry out problem solving activities, not only learn theoretically to solve problems. In practice, the teacher needs to train students gradually and receive feedback on the problem-solving process they do (Jonassen, 2011). PBL encourages students to analyze problems and make hypotheses about these problems. Next, students discuss in groups to prove the truth of the hypothesis. Reporting student work is done through simulations to other groups to get responses or feedback from fellow students and teachers. Feedback is needed to confirm the relationship between the variables raised by the hypothesis. In this process students will be shown mental models that are formed during the problem solving process. The results of interviews that show students' mental models on the surface, matching and deep levels are shown in Table 4.

The summary results of other students' answers at the microscopic level can be explained as follows. First students will assemble tools according to the instructions in the worksheet then students measure the length of the spring first. The results of communication between teacher $(\mathrm{T})$ and student $(\mathrm{S})$ are as fol-

Table 2. Anacova Test Results The Effect of Learning Models on Students' Mental Models

\begin{tabular}{lccccc}
\hline Source & Type III Sum of Squares & Df & MeanSquare & F & Sig. \\
\hline Corrected Model & $4147.9^{a}$ & 2 & 2073.9 & 63.7 & .000 \\
Intercept & 46154.3 & 1 & 46154.3 & 1418.1 & .000 \\
Xmodel & 1.5 & 1 & 1.5 & .05 & .831 \\
Model & 4144.0 & 1 & 4144 & 127.3 & .000 \\
Error & 2408.5 & 74 & 32.5 & & \\
Total & 373070.5 & 77 & & & \\
Corrected Total & 6556.315 & 76 & & & \\
\hline
\end{tabular}

$\mathrm{R}$ Squared $=0.633 ;($ Adjusted $\mathrm{R}$ Squared $=0.623)$

Table 3. LSD Test Results The Effect of Learning Models on Mental Models

\begin{tabular}{lcccccc}
\hline \multicolumn{1}{c}{ Model } & $\begin{array}{c}\text { Xmodel } \\
\text { mental }\end{array}$ & $\begin{array}{c}\text { Ymodel } \\
\text { mental }\end{array}$ & Difference & MM corrected & LSD Notation & $\begin{array}{c}\text { Increasement } \\
(\%)\end{array}$ \\
\hline PBL & 31.8211 & 76.4263 & 44.6052 & 76.425 & $\mathrm{a}$ & 140.17 \\
Conventional & 32.0949 & 61.7487 & 29.6538 & 61.750 & $\mathrm{~b}$ & 92.39 \\
\hline
\end{tabular}


Table 4. Qualitative Summary of Student Answer Results

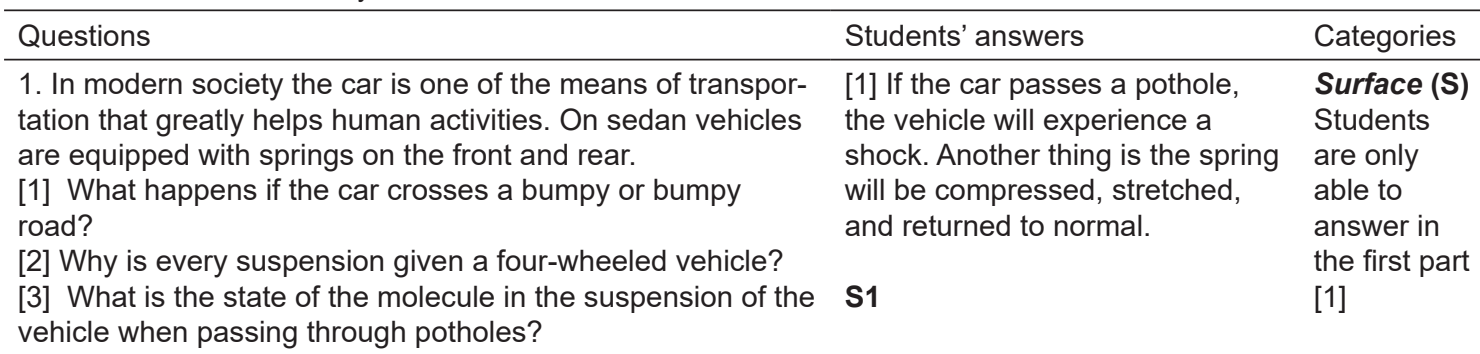

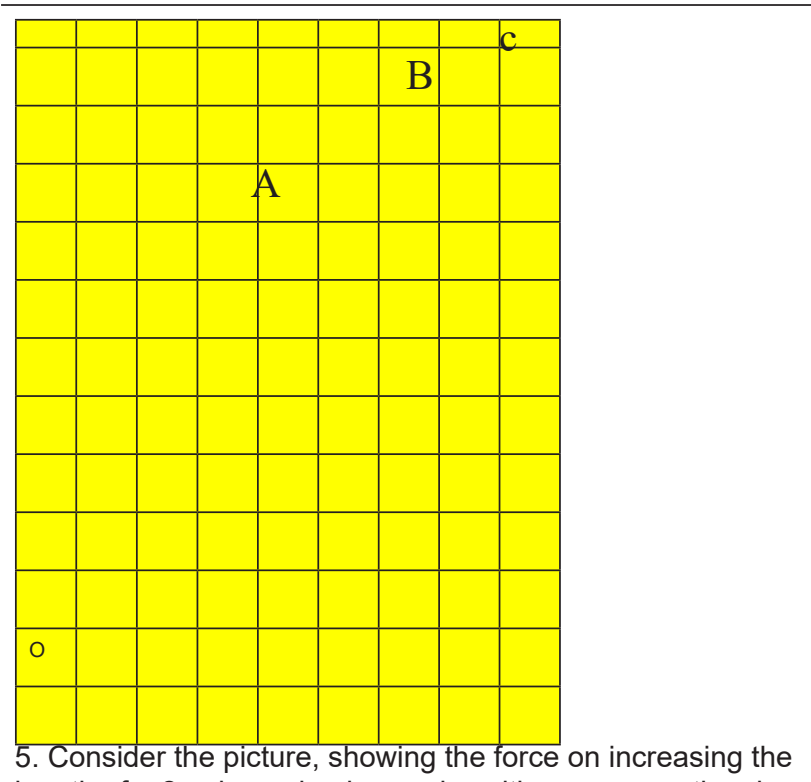
length of a $2 \mathrm{~m}$ long aluminum wire with a cross-sectional area of $1 \mathrm{~mm}^{2}$. Point $A$ is called the elasticity limit; the length addition is proportional to the tensile force. OA is called the elastic region and Hooke's law applies.

[1] What happens to the OA region, if the tensile force is removed?

[2] Explain what if the tensile strength is at point $B$ ?

[3] What is the condition of the molecule, if the pull force is at point $\mathrm{C}$ ?

\footnotetext{
6. A number 1 archery athlete in Indonesia took part in the 2018 Olympic archery championship in Brazil.

[1] What happens if the athlete pulls with a large enough bow style?

[2] Explain why this is so?

[3] What is the state of particles, when an athlete pulls a bowstring tight enough?
}

[1] If the pulling force is removed at the OA point, the wire will

Matching return to its original shape.

[2] If the tensile force is at point Students are only $\mathrm{B}$, then the area is the maximum answer in critical limit or the maximum force the first part applied to the wire without break- [1] and [2] ing it or is called the bend point.

\section{S25}

[1] If the athlete exerts a sufficiently large force then the stress and strain values are also large and the arrows will move faster. [2] Because the amount of pull on the bowstring affects the velocity of the object. The greater the tensile force, the faster the arrow moves. Thus the distance traveled is also getting further. [3] Bows have elastic properties so that when an athlete pulls a bow, the constituent particles of the bowstring and bow move away from the equilibrium position and resist resistance to deformation (London style). Resistance arises in the form of a reaction force to maintain its shape.

\section{Deep (D)} Students are able to answer all questions well 
lows.

The student anser that "by adding the load or mass to the spring will result :

Particles which were initially at rest will moved fast. The distance between particles is farther away". Information:

$\mathrm{T}=$ teacher

S3 = student number 3 on the class attendance list

S20 $=$ student number 20 on the class attendance list

$T \quad$ : Measure the length of the spring first using a ruler.

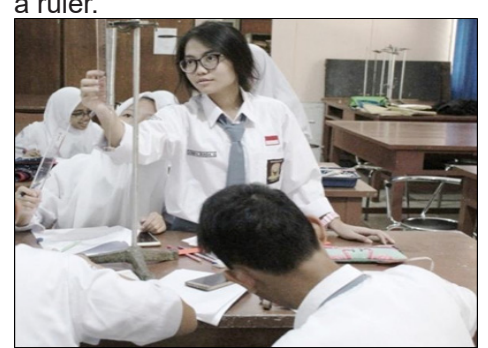

Students were try to describe how is the state of the particle when the spring has not been given any weight.

S3 : The state of particles in a normal or stationary state

$$
\begin{aligned}
& 00000000000000 \\
& 00000000000000 \\
& 00000000000000 \\
& 000000000000 \\
& 00000000000 \\
& 0000000000
\end{aligned}
$$

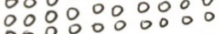

$\mathrm{T} \quad$ : Please add weight to a spring and measure the length of the spring.

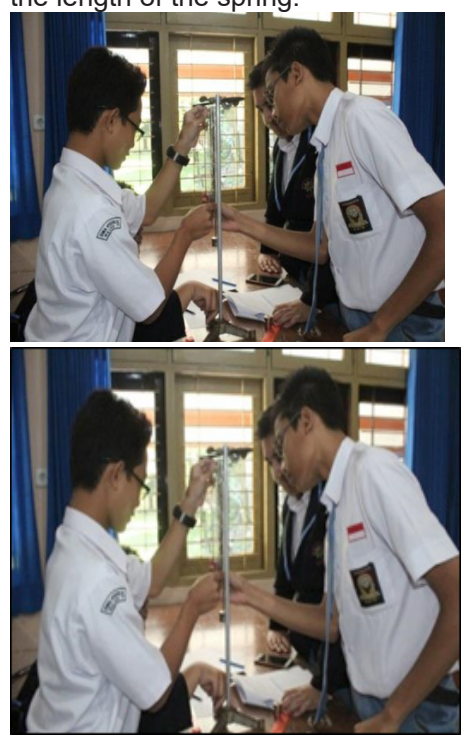

Students were try to tell and describe how is the state of particle when given $200 \mathrm{~g}$ of weight.
S20

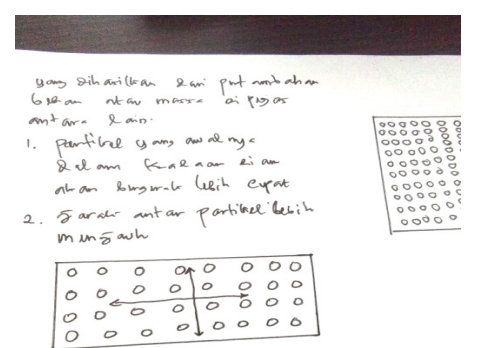

\section{CONCLUSION}

Based on the discussion of the results of the study it is concluded that the application of PBL had an effective effect in improving students' mental models on the concept of material elasticity of solids. Thus PBL can be applied to improve students' mental models on the material elasticity of solids. The implication of this research is to provide good information to teachers and scholars that PBL is very good in improving students' conceptual abilities. Limitations in this study are still in one aspect, namely measuring students' mental models on the concept of elasticity. Therefore ongoing research to explore other dependent variables that can make a positive contribution in learning physics still needed.

\section{REFERENCES}

Adbo, K., \& Taber, K. S. (2009). Learners' mental models of the particle nature of matter: A study of 16-year-old swedish science students. International Journal of Science Education, 31(6), 757-786. https://doi. org/10.1080/09500690701799383

Ahi, B. (2016). A study to determine the mental models in preschool children's conceptualization of a desert environment. International Electronic Journal of Elementary Education, 8(3), 333-350.

Banks, A. P., \& Millward, L. J. (2000). Running shared mental models as a distributed cognitive process. British Journal of Psychology, 91(4), 513-531. https://doi. org/10.1348/000712600161961

Batlolona, J. R., Diatoro, M., Wartono., \& Latifah, E. (2019). Creative Thinking Skills Students in Physics on Solid Material Elasticity. Journal of Turkish Science Education, 16(1), 48-61. (https://doi.org/10.12973/tused.10265a

Bongers, A., Northoff, G., \& Flynn, A. B. (2019). Working with mental models to learn and visualize a new reaction mechanism. Chemistry Education Research and Practice, 
20(3), 554-569. https://doi.org/10.1039/ c9rp00060g

Cheng, M. F., \& Lin, J. L. (2015). Investigating the Relationship between Students' Views of Scientific Models and Their Development of Models. International Journal of Science Education, 37(15), 2453-2475. https://doi.org/1 $0.1080 / 09500693.2015 .1082671$

Chiou, G. L., \& Anderson, O. R. (2010). A study of undergraduate physics students' understanding of heat conduction based on mental model theory and an ontology-process analysis. Science Education, 94(5), 825-854. https:// doi.org/10.1002/sce.20385

Creswell, J., \& Plano, C. V. (2007). Designing and Conducting Mixed Methods Research. United States of Amerika: Sage Publication, Inc

Dankenbring, C., \& Capobianco, B. M. (2016). Examining Elementary School Students' Mental Models of Sun-Earth Relationships as a Result of Engaging in Engineering Design. International Journal of Science and Mathematics Education, 14(5), 825-845. https:// doi.org/10.1007/s10763-015-9626-5

Doran, R., Böhm, G., \& Hanss, D. (2018). Using card sorting to explore the mental representation of energy transition pathways among laypeople. Frontiers in Psychology, 9(DEC), 1-11. https://doi.org/10.3389/fpsyg.2018.02322

Fernandez, F. B. (2017). Action research in the physics classroom: the impact of authentic, inquiry based learning or instruction on the learning of thermal physics. Asia-Pacific Science Education, 3(1). https://doi.org/10.1186/ s41029-017-0014-z

Furlough, C. S., \& Gillan, D. J. (2018). Mental Models: Structural Differences and the Role of Experience. Journal of Cognitive Engineering and Decision Making, 12(4), 269-287. https://doi.org/10.1177/1555343418773236

Gabe-Thomas, E., Walker, I., Verplanken, B., \& Shaddick, G. (2016). Householders' mental models of domestic energy consumption: Using a sort-and-cluster method to identify shared concepts of appliance similarity. PLoS ONE, 11(7), 1-15. https://doi.org/10.1371/ journal.pone.0158949

Greca, I. M., \& Moreira, M. A. (2000). International Journal of Science Education Mental models , conceptual models, and modelling. International Journal of Science Education, 22(1), $1-11$.

Hapsoro, C. A., \& Susanto, H. (2011). Penerapan Pembelajaran Problem Based Instruction Berbantuan Alat Peraga Pada Materi Cahaya Di Smp. Jurnal Pendidikan Fisika Indonesia, 7(1), 28-32. https://doi.org/10.15294/jpfi. v7i1.1065

Hodges, L. C. (2018). Contemporary issues in group learning in undergraduate science classrooms: A perspective from student engagement. CBE Life Sciences Education, 17(2),
1-10. https://doi.org/10.1187/cbe.17-11-0239

Hubber, P. (2006). Year 12 students' mental models of the nature of light. Research in Science Education, 36(4), 419-439. https://doi. org/10.1007/s11165-006-9013-x

Ifenthaler, D. 2006. Diagnose lernabhängiger Veränderung mentaler Modelle. Entwicklung der SMD Technologie als methodologisches Verfahren zur relationalen, strukturellen und semantischen Analyse individueller Modellkonstruktionen. Freiburg: UniversitätsDissertation. (Diagnosis of the learningdependent progression of mental models. Development of the SMD-Technology as a methodology for assessing individual models on relational, structural and semantic levels).

Itza-Ortiz, S. F., Rebello, S., \& Zollman, D. (2004). Students' models of Newton's second law in mechanics and electromagnetism. European Journal of Physics, 25(1), 81-89. https://doi. org/10.1088/0143-0807/25/1/011

Langbeheim, E. (2015). A project-based course on Newton's laws for talented junior high-school students. Physics Education, 50(4), 410-415. https://doi.org/10.1088/0031-9120/50/4/410

Leasa, M., \& Corebima, A. D. (2017). The effect of numbered heads together (NHT) cooperative learning model on the cognitive achievement of students with different academic ability. Journal of Physics: Conf. Series, 795 (2017) 012071. https:doi. org/ 10.1088/17426596/795/1/012071

Lin, J. W., \& Chiu, M. H. (2007). Exploring the characteristics and diverse sources of students' mental models of acids and bases. International Journal of Science Education, 29(6), 771-803. https://doi. org/10.1080/09500690600855559

Lycke, K. H., Grøttum, P., \& Strømsø, H. (2006). Student learning strategies, mental models and learning outcomes in problem-based and traditional curricula in medicine. Medical Teacher, 28(8), 717-722. https://doi. org/10.1080/01421590601105645

O Doherty, D., Mc Keague, H., Harney, S., Browne, G., \& McGrath, D. (2018). What can we learn from problem-based learning tutors at a graduate entry medical school? A mixed method approach. BMC Medical Education, 18(1), 1-12. https://doi.org/10.1186/s12909-0181214-2

Pasco, D., \& Ennis, C. D. (2015). Third-grade students' mental models of energy expenditure during exercise. Physical Education and Sport Pedagogy, 20(2), 131-143. https://doi. org/10.1080/17408989.2013.803525

Reinfried, S., \& Tempelmann, S. (2014). The Impact of Secondary School Students' Preconceptions on the Evolution of their Mental Models of the Greenhouse effect and Global Warming. International Journal of Science Education, 36(2), 304-333. https://doi.org/10.1080 
/09500693.2013.773598

Schnittka, C., \& Bell, R. (2011). Engineering design and conceptual change in science: Addressing thermal energy and heat transfer in eighth grade. International Journal of Science Education, 33(13), 1861-1887. https://doi.org/10 $.1080 / 09500693.2010 .529177$

Servant-Miklos, V. F. C. (2019). Fifty Years on: A Retrospective on the World's First Problembased Learning Programme at McMaster University Medical School. Health Professions Education, 5(1), 3-12. https://doi. org/10.1016/j.hpe.2018.04.002

Smit, K., de Brabander, C. J., \& Martens, R. L. (2014). Student-centred and teacher-centred learning environment in pre-vocational secondary education: Psychological needs, and motivation. Scandinavian Journal of Educational Research, 58(6), 695-712. https://doi. org/10.1080/00313831.2013.821090

Stains, M., \& Sevian, H. (2015). Uncovering Implicit
Assumptions: a Large-Scale Study on Students' Mental Models of Diffusion. Research in Science Education, 45(6), 807-840. https://doi.org/10.1007/s11165-014-9450-x

Stewart, C., \& Bower, M. (2019). Novice online educator conceptual frameworks: a mental model exploration of mindful learning design. Educational Media International, 56(1), 14-43. https://doi.org/10.1080/09523987.20 19.1583463

Wartono., Diantoro., \& Batlolona, J. R. (2018). Influence of problem based learning model on student creative thinking on elasticity topics a material. Jurnal Pendidikan Fisika Indonesia, 14(1), 32-39.

Yogantari, P. (2015). Indentifikasi Kesulitan Siswa dalam Pembelajaran Fisika. Seminar Nasional Fisika dan Pembelajarannya. Jurusan Fisika Universitas Negeri Malang. Malang, 29 Agustus 2019. 7-11. 